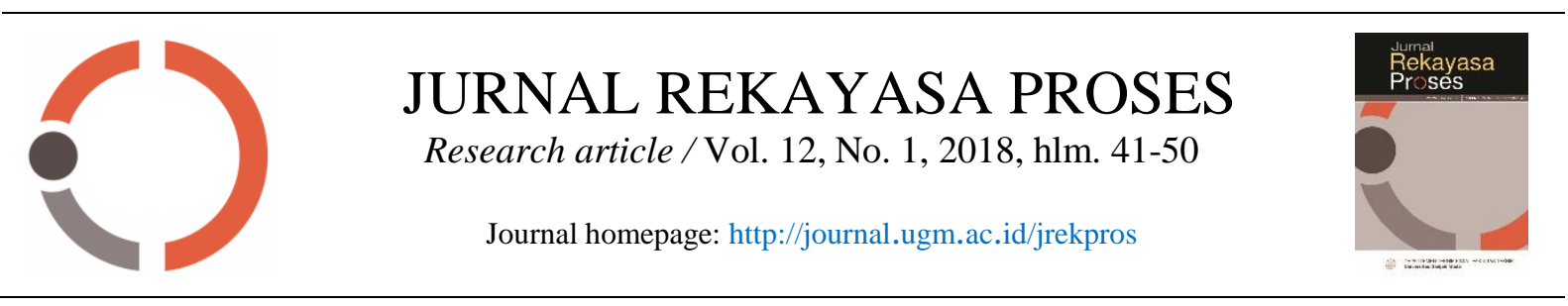

\title{
Nilai Parameter Kadar Pencemar sebagai Penentu Tingkat Efektivitas Tahapan Pengolahan Limbah Cair Industri Batik
}

\author{
Lilin Indrayani ${ }^{1 *}$ dan Nur Rahmah ${ }^{2}$ \\ ${ }^{1}$ Balai Besar Kerajinan dan Batik, Jalan Kusumanegara No.7 Yogyakarta \\ ${ }^{2}$ Departemen Kimia, Institut Pertanian Bogor, Gedung Kimia Wing 1 Level 3, Jalan Tanjung. Bogor \\ *Alamat korespondensi: indrayanililin@gmail.com
}

(Submisi: 23 Mei 2018; Revisi: 25 Juni 2018; Penerimaan: 30 Juni 2018)

\section{A B S T RACT}

Batik industry sector has a strategic role in development, especially to increase the level of employment and its contribution in encouraging the growth of creative economy. Along with the development of batik industry that has been known globally, batik industry produces a negative impact of liquid waste in a large amount which will potentially pollute the environment. This paper described the characteristics of batik industrial wastewater and its treatment stages both in physics, chemistry and biology. The treated wastewater is analyzed and adjusted to the required wastewater quality standard parameters. The wastewater treatment plant in Balai Besar Kerajinan dan Batik (BBKB) consist of physical process i.e. sedimentation, biological process i.e. anaerobic treatment and chemical process i.e. coagulation. The efficiency of the process is determined by the value of test results at each stage of wastewater treatment. The efficiency of physical, biological and chemical process in this plant were $71.69 \% ; 55,31 \% ; 40.75 \%$, respectively. According to the results, the treated wastewater could be discharged safely to the environment.

Keywords: batik industry, waste water, waste water treatment plant (WWTP), level of effectivity

\section{A B S T R A K}

Sektor industri batik mempunyai peranan strategis dalam pembangunan, terutama untuk menumbuhkan tingkat penyerapan tenaga kerja serta kontribusinya dalam mendorong pertumbuhan ekonomi kreatif. Seiring dengan perkembangan industri batik yang sudah dikenal secara global, industri batik menghasilkan dampak negatif berupa limbah cair dalam kuantitas cukup besar yang berpotensi mencemari lingkungan. Dalam makalah ini dijelaskan karateristik limbah cair industri batik dan tahapan pengolahan limbah baik secara fisika, kimia dan biologi. Limbah yang telah diolah dianalisis dan disesuaikan dengan parameter baku mutu limbah yang dipersyaratkan. Dari nilai hasil pengujian dilakukan perhitungan nilai efisiensi pada tiap tahapan pengolahan limbah. Instalasi pengolahan limbah cair batik di IPAL BBKB menggunakan proses pengolahan fisika yaitu sedimentasi; pengolahan biologis dengan pemanfaatan bakteri anaerob; pengolahan kimia dengan penambahan koagulasi. Efektivitas pengolahan dari proses-fisika, biologi dan kimia tersebut berturutturut adalah $71,69 \% ; 55,31 \% ; 40,75 \%$. Keseluruhan kadar pencemar mengalami penurunan nilai sehingga limbah cair batik yang telah dilakukan pengolahan pada IPAL BBKB dapat dinyatakan aman untuk dibuang ke lingkungan.

Kata kunci: industri batik, limbah cair, instalasi pengolahan air limbah (IPAL), tingkat efektivitas 


\section{Pendahuluan}

Semakin berkembangnya industri batik di Indonesia ditandai dengan semakin banyaknya jumlah sentra industri batik baru yang bermunculan. Selain memberi manfaat bagi peningkatan ekonomi, industri batik berpotensi memberikan dampak pencemaran lingkungan. Hal tersebut terjadi akibat banyaknya bahan kimia yang digunakan selama proses pembuatan batik. Bahan yang dapat menimbulkan masalah pencemaran adalah bahan organik, non-organik, dan logam berat dengan konsentrasi yang dapat melebihi nilai baku mutu yang diperbolehkan untuk masuk ke lingkungan.

Industri batik merupakan penghasil limbah cair dengan kuantitas yang cukup besar, warna yang pekat dan berbau menyengat. Selain itu, limbah cair batik memiliki karateristik suhu, derajat keasaman $(\mathrm{pH})$, biological oxygen demand (BOD), chemical oxygen demand (COD), serta total suspended solid (TSS) yang tinggi (Rohasliney dan Subki, 2011). Suhu yang tinggi akan mengakibatkan kandungan oksigen terlarut dalam air menurun yang akan membunuh organisme dan limbah organik akan meningkatkan kadar nitrogen menjadi senyawa nitrat yang menyebabkan bau busuk (Sastrawijaya, 2009).

Hal ini disebabkan oleh penggunaan bahan kimia terutama dalam proses pencelupan atau pewarnaan, pelorodan serta pencucian pada proses produksi batik. Bahan kimia yang digunakan dalam proses pembuatan batik antara lain: zat warna sebagai bahan kimia utama dan bahan kimia pembantu yaitu soda kaustik $(\mathrm{NaOH})$, soda abu $\left(\mathrm{Na}_{2} \mathrm{CO}_{3}\right)$, soda kue $\left(\mathrm{NaHCO}_{3}\right)$, asam sulfat $\left(\mathrm{H}_{2} \mathrm{SO}_{4}\right)$, sulfit, dan nitrit (Muljadi dan Muniarti 2013). Sedangkan zat warna yang digunakan antara lain: zat warna asam, zat warna basa, zat warna direk, zat warna reaktif, zat warna naftol, dan zat warna bejana. Selain itu komponen dari zat mordan (pengunci warna) yang digunakan dalam proses fiksasi pada pembuatan kain batik menggunakan beberapa unsur zat kimia, antara lain: tawas $\left(\mathrm{KAl}\left(\mathrm{SO}_{4}\right)_{2}\right)$, tunjung $\left(\mathrm{Fe}\left(\mathrm{SO}_{4}\right)\right)$, pijer/boraks, air kapur $\left(\mathrm{Ca}(\mathrm{OH})_{2}\right)$, kalsium karbonat $\left(\mathrm{CaCO}_{3}\right)$, kalsium hidroksida $\left(\mathrm{Ca}(\mathrm{OH})_{2}\right)$, asam sitrat $\left(\mathrm{C}_{6} \mathrm{H}_{8} \mathrm{O}_{7}\right)$, tembaga(II) sulfat $\left(\mathrm{Cu}_{2}\left(\mathrm{CH}_{3} \mathrm{COO}\right)_{4}\right)$, besi sulfat $\left(\mathrm{FeSO}_{4} \cdot 7 \mathrm{H}_{2} \mathrm{O}\right)$, dan kalium dikromat $\left(\mathrm{K}_{2} \mathrm{Cr}_{2} \mathrm{O}_{7}\right)$. Apabila air limbah dibuang ke lingkungan tanpa dilakukan pengolahan terlebih dahulu, maka dapat menyebabkan pencemaran lingkungan terutama ekosistem perairan.

Limbah cair batik pada umumnya bersifat basa dan memiliki kadar organik yang tinggi akibat sisa proses pembatikan. Proses pencelupan yang dilakukan merupakan penyumbang zat warna yang kuat apabila tidak diberikannya pengolahan yang tepat. Zat warna yang terkandung dalam limbah cair batik umumnya sukar untuk terdegradasi dengan baik. Zat warna ini umumnya didesain untuk memiliki tingkatan kimia yang tinggi untuk menahan kerusakan akibat oksidatif yang berasal dari cahaya matahari (Manurung dkk., 2004). Karakteristik air limbah ini dapat digolongkan menjadi tiga macam, yaitu: karakteristik fisik, kimia, dan biologi.

Industri batik menghasilkan limbah cair dengan kandungan organik yang besar, warna yang pekat, berbau menyengat, dan memiliki suhu yang tinggi. Nilai keasaman $(\mathrm{pH})$, biochemical oxygen demand (BOD), chemical oxygen demand (COD), dan total suspended solid (TSS) yang dihasilkan juga tinggi (Kurniawan dkk., 2013). Karakteristik fisik limbah cair meliputi temperatur, bau, warna, dan padatan. Temperatur menunjukkan derajat atau tingkat panas air limbah yang ditunjukkan ke dalam skala. Suhu dapat mempengaruhi kadar Dissolved Oxygen (DO) dalam air. Kenaikan temperatur sebesar $10^{\circ} \mathrm{C}$ dapat menyebabkan penurunan kadar oksigen sebesar $10 \%$ dan akan mempercepat metabolisme 2 kali lipat. Adanya bau yang lain pada air limbah, menunjukkan adanya komponen lain dalam air tersebut. Warna biasanya disebabkan oleh adanya materi dissolved, suspended, dan senyawa-senyawa koloid, yang dapat dilihat dari spektrum warna yang terjadi. Padatan yang terdapat di dalam air limbah dapat diklasifikasikan menjadi floating, settleable, suspended atau dissolved, berbau menyengat, dan kontaminan akan membuat air menjadi keruh. Timbulnya gejala tersebut secara 
mutlak dapat dipakai sebagai salah satu tanda terjadinya tingkat pencemaran air yang cukup tinggi (Wardhana 2004).

Karakteristik kimia meliputi chemical oxygen demand (COD), $\mathrm{pH}$, dan DO. Nilai COD merupakan banyaknya oksigen dalam $\mathrm{mg} / \mathrm{L}$ yang dibutuhkan untuk menguraikan bahan organik secara kimiawi. Semakin tinggi kadar COD maka semakin buruk kualitas air tersebut. Dissolved oxygen (DO) merupakan sebuah ukuran banyaknya kandungan oksigen yang terlarut dalam air. Oksigen terlarut ini merupakan hal yang paling penting untuk ikan. Kandungan DO optimum untuk ikan adalah 5-6 mg/L, sedangkan kadar DO minimum adalah $3 \mathrm{mg} / \mathrm{L}$. Nilai $\mathrm{pH}$ merupakan indikator untuk menunjukkan derajat keasaman dalam perairan. Ikan dapat hidup pada kisaran $\mathrm{pH}$ 5-9. Ikan akan mati apabila $\mathrm{pH}$ dalam air kurang dari 4 atau lebih dari 11. Karakteristik biologi, mikroorganisme ditemukan dalam jenis yang sangat bervariasi hampir dalam semua bentuk air limbah, biasanya dengan konsentrasi 105-108 organisme/mL. Keberadaan bakteri dalam unit pengolahan air limbah merupakan kunci efisiensi proses biologis. Bakteri juga berperan penting untuk mengevaluasi kualitas air (Purwaningsih 2008).

Dalam penelitian ini bertujuan untuk mengetahui tingkat efektivitas kinerja pengolahan IPAL BBKB dalam menurunkan kandungan pencemar limbah cair industri batik. Limbah dengan karakteristik tersebut diatas menimbulkan dampak kerusakan lingkungan dan kesehatan manusia dalam jangka waktu yang panjang dan kian meluas. Untuk itu diperlukan suatu tahapan pengolahan limbah cair. Pengolahan limbah cair secara umum dapat dilakukan secara fisika, kimia, dan biologi. Seluruh proses tersebut bertujuan untuk menghilangkan kandungan padatan tersuspensi, koloid, dan bahan-bahan organik yang terlarut dalam limbah cair industri batik (Eskani, 2005).

\section{Metode Penelitian}

Metode yang digunakan pada penelitian ini adalah dengan menggunakan data pengoperasian IPAL Batik, Balai Besar Kerajinan dan Batik
(BBKB) dengan pengambilan data sampel limbah cair pada setiap triwulan pada tiap tahapan pengolahan dalam waktu satu tahun yaitu selama tahun 2017. Hal ini didasarkan pada asumsi bahwa IPAL BBKB dapat mewakili IPAL industri batik karena bahan kimia dan proses produksi yang dilakukan di BBKB sama dengan aktivitas yang dilakukan pada industri batik pada umumnya.

\subsection{Prinsip Pengolahan Limbah Cair BBKB}

Pengolahan limbah cair untuk mengatasi limbah industri batik di BBKB dilakukan dengan metode fisika, kimia, dan biologi untuk menurunkan kadar parameter pencemar. Adapun skema pengolahan limbah cair tersebut dilakukan sesuai Gambar 1 dan Gambar 2.

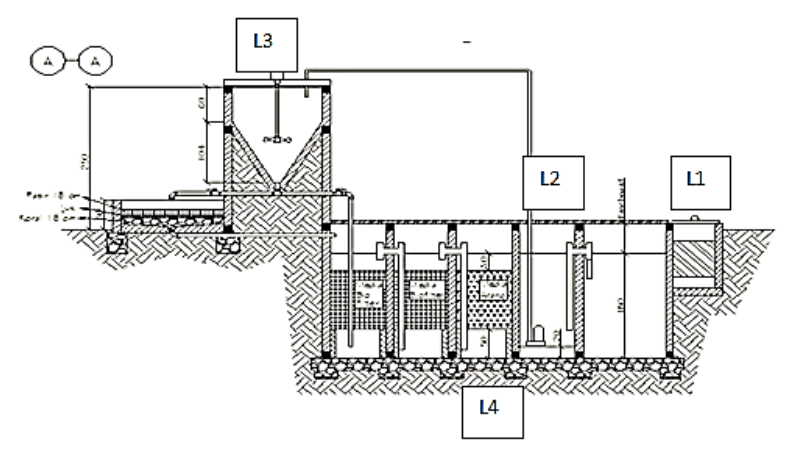

Gambar 1. Tampak samping IPAL BBKB

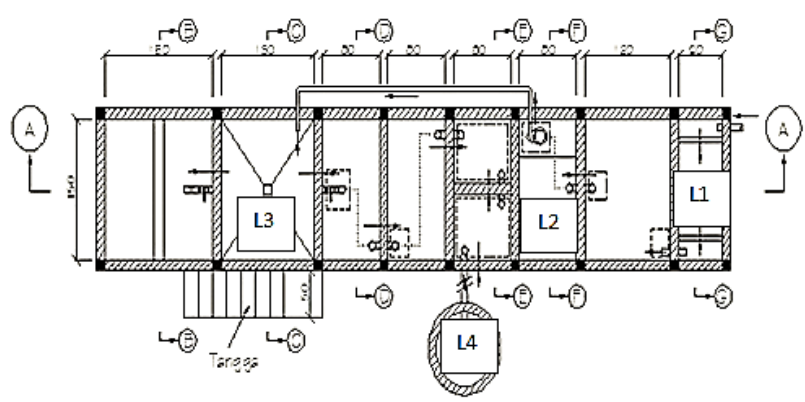

Gambar 2. Penampang atas IPAL BBKB

Sistem pengolahan fisika diterapkan melalui proses sedimentasi, pengolahan kimia dengan proses koagulasi dan flokulasi, dan pengolahan biologi dengan memanfaatkan bakteri anaerob, serta dilanjutkan dengan pengolahan fisika-kimia dengan adsorbsi arang. Penjelasan sistem pengolahan secara keseluruhan adalah sebagai berikut: 
1. Penangkap limbah lilin batik (L1)

Bak penangkap lilin batik (wax trap tank) terdapat di dekat instalasi lorodan. Limbah lilin dari bak pencucian setelah lorodan dialirkan dan didiamkan pada bak ini. Limbah lilin batik yang mengapung ataupun yang mengendap secara berkala dikeluarkan secara manual untuk diolah kembali menjadi lilin. Selain berfungsi sebagai penangkap limbah lilin batik, bak ini juga berfungsi untuk menangkap padatan inorganik seperti pasir, tanah, dan lain-lain. Tutup dari bak ini dibuat dari plat stainless steel supaya ringan, karena frekuensi buka dan tutupnya cukup sering. Air limbah dari bak wax trap selanjutnya masuk ke bak ekualisasi (equalitation dan sedimentation tank).

2. Bak ekualisasi dan sedimentasi awal (L2)

Bak ini berfungsi untuk hoomogenisasi kandungan organik maupun anorganik dalam air limbah dari proses pembatikan. Bak ekualisasi ini dikombinasi dengan bak sedimentasi untuk mengendapkan padatan organik dalam air limbah, sehingga total padatan tersuspensi dalam limbah (TSS) akan turun dan meringankan sistem pengolahan selanjutnya. Bak ini juga berfungsi sebagai bak tandon. Bila sudah penuh, air limbah dalam bak ini baru dipompa masuk ke bak pengolahan kimia (coagulation dan mixing tank).

3. Bak pengolahan kimia (coagulation dan mixing tank) (L3)

Dari bak sedimentasi awal, air limbah masuk ke bak koagulasi. Air limbah akan dipompakan masuk ke bak pengolahan kimia (coagulation dan mixing tank). Pompa memakai jenis pompa celup untuk air kotor/ sewage pump, dengan motor $1 / 3-1 / 2$ HP dan head $>7 \mathrm{~m}$. Dalam bak pengolahan kimia dilengkapi dengan peralatan pengaduk (mixer) otomatis yang digunakan sebagai pengaduk untuk menjaga homogenitas limbah. Adapun spesifikasi mixer yang digunakan adalah motor listrik $1 \mathrm{HP}$, panjang as mixer $1,1 \mathrm{~m}$, diameter kipas $30 \mathrm{~cm}$, lebar kipas $8 \mathrm{~cm}$, kemiringan sudut $35^{\circ}$, dan kecepatan putar $100 \mathrm{rpm}$.
Pengolahan kimia yang dilakukan pada bak ini meliputi proses netralisasi, koagulasi, dan flokulasi. Air limbah dari berbagai macam proses setelah dikumpulkan pada bak 4 (pengolahan kimia) perlu diperiksa $\mathrm{pH}$-nya dan dinetralkan. Jika air limbah bersifat basa maka perlu ditambah asam, dan sebaliknya jika air limbah bersifat asam maka perlu diberi basa supaya netral $(\mathrm{pH}=7)$. Koagulasi merupakan tingkat pengolahan dengan cara menambahkan atau mencampurkan bahan kimia (koagulan) pada air limbah dan selanjutnya diaduk cepat dalam bentuk larutan tercampur. Koagulan yang sering dipakai $\mathrm{Al}_{2}(\mathrm{SO}) 4.18 \mathrm{H}_{2} \mathrm{O}$ yang di pasaran lebih dikenal dengan nama tawas. Pemilihan koagulan ini dengan alasan mudah didapat dan harganya relatif murah.

4. Bak Pengering Lumpur (Sand bed dryer)

Fungsi unit ini adalah untuk pengeringan lumpur yang dihasilkan dari proses koagulasi dan flokulasi. Konstruksinya terdiri dari bak dengan bagian bawah diberi tumpukan batu (kurang lebih $10 \mathrm{~cm}$ ) dan di atas batu diberi lapisan pasir kasar, sehingga kandungan air pada lumpur basah akan diperas secara gravitasi. Air perasan dimasukkan pada unit pengolahan sedangkan lumpurnya tinggal di permukaan pasir dan terjemur matahari menjadi kering.

5. Pengolahan secara biologi pada kondisi anaerob

Proses ini menggunakan teknologi filter anaerobik. Waktu tinggal pada pengolahan anaerob ini adalah 48 jam, dan terdiri dari 2 buah bak filter anaerobik. Pada filter anaerobik tumbuh mikroba anaerob yang pertumbuhannya melekat (attached). Sehingga di dalam bak ini akan dimasukkan media biofilm (biofilter). Adapun media biofilm yang digunakan adalah tipe DD-01 dengan specific surface area $160 \mathrm{~m}^{2} / \mathrm{m}^{3}$ dan void ratio nya $95 \%$.

6. Pengolahan fisika-kimia dengan adsorbsi arang

Pengolahan adsorbsi arang dimaksudkan sebagai tambahan untuk mengikat logam berat dan zat pewarna, supaya kualitas effluent-nya 
lebih baik. Adsorben yang akan digunakan adalah arang kayu atau arang batok kelapa, dengan bentuk blok $5 \mathrm{~cm}$.

7. Bak kontrol (L4)

Fungsi bak kontrol adalah untuk memudahkan pengambilan sampel air limbah akhir dalam rangka pengujian kualitas air limbah sebelum dibuang ke lingkungan. Jadi L4 merupakan sampel limbah batik yang telah dilakukan pengolahan secara biologi dengan menggunakan bakteri anaerob dan telah melewati proses absorbsi arang.

8. Sumur resapan

Sumur resapan dibuat untuk membuang air limbah yang telah diproses kembali ke alam.

\subsection{Alat dan Bahan}

Alat-alat yang digunakan antara lain: botol Winkler, pipet, gelas kimia, gelas ukur, inkubator, tabung reaksi, termometer, COD reaktor, spektrofotometer, COD tube, magnetic stirrer, buret, dan peralatan kaca lainnya. Bahan yang digunakan adalah limbah cair batik yang berasal dari IPAL BBKB, tawas, aquades, $\mathrm{MnSO}_{4}, \quad \mathrm{NaOH}-\mathrm{KI}, \quad \mathrm{H}_{2} \mathrm{SO}_{4}, \quad \mathrm{Na}_{2} \mathrm{~S}_{2} \mathrm{O}_{3}, \quad$ dan pereaksi $\mathrm{K}_{2} \mathrm{Cr}_{2} \mathrm{O}_{7}-\mathrm{HgSO}_{4}$.

\subsection{Pengujian Sampel Limbah Cair IPAL BBKB}

Pengujian sampel dilakukan di laboratorium lingkungan yang terakreditasi yaitu di Balai Teknik Kesehatan Lingkungan (BTKL), Kementerian Kesehatan, Provinsi Daerah Istimewa Yogyakarta (DIY) dengan standar peraturan daerah DIY Nomor 7 Tahun 2016 tentang baku mutu air limbah bagi industri batik. Adapun parameter pencemar yang diuji dan metode pengujian yang dipakai disesuaikan dengan peraturan perundangan yang berlaku yaitu sebagai berikut:

Tabel 1. Parameter dan metode pengujian limbah batik

\begin{tabular}{cccc}
\hline No & Parameter & Satuan & Metode Uji \\
\hline 1 & BOD $_{5}$ & $\mathrm{mg} / \mathrm{L}$ & SNI 6989.72-2009 \\
2 & COD & $\mathrm{mg} / \mathrm{L}$ & SNI 6989.2-2009 \\
3 & TSS & $\mathrm{mg} / \mathrm{L}$ & In House Method \\
4 & $\mathrm{pH}$ & - & SNI 06-6989.23-2005 \\
5 & Suhu & ${ }^{\circ} \mathrm{C}$ & SNI 06-6989.11-2004 \\
\hline
\end{tabular}

\subsection{Nilai Efektifitas Kinerja IPAL BBKB}

Pengkajian kinerja IPAL BBKB dilakukan dengan cara membandingkan air limbah sebelum pengolahan dan setelah pengolahan. Analisis data efisiensi instalasi pengolahan limbah cair dilakukan berdasarkan penurunan parameter pencemar air buangan, di antaranya parameter pencemar dapat dirumuskan pada Persamaan 1.

$$
E=\frac{C o-C i}{C o} \times 100 \%
$$

Dengan:

$E \quad=$ efisiensi (\%)

Co $=$ konsentrasi parameter pencemar sebelum diolah

$\mathrm{Ci}=$ konsentrasi parameter pencemar setelah diola

\section{Hasil dan Pembahasan}

\subsection{Sistem Instalasi Pengolahan Air Limbah Batik}

Maksud dan tujuan pengolahan air limbah industri batik adalah untuk menurunkan atau mengurangi kadar unsur pencemar dari limbah cair batik dan untuk mendapatkan effluent dari pengolahan yang mempunyai kualitas yang dapat diterima oleh badan air penerima. Buangan tidak mengandung gangguan fisik, kimia, dan biologi, atau dengan kata lain limbah cair hasil olahan IPAL menjadi layak buang sesuai standar baku mutu yang ditentukan. Proses pengolahan limbah tidak mungkin menghilangkan sama sekali konsentrasi bahan pencemar, tetapi hanya menurunkan atau meminimalkan bahan pencemar.

Pengolahan adalah proses yang dilakukan sehingga menyebabkan terjadinya perubahan akibat proses fisika, kimia, dan biologi dengan melibatkan satuan operasi atau satuan proses pada unit-unit bangunan pengolahan. Ada tiga cara pengolahan air limbah batik berdasarkan karakteristik limbah, yaitu:

1. Pengolahan air limbah secara fisika yang bertujuan menyisihkan atau memisahkan bahan pencemar tersuspensi atau melayang yang berupa padatan dari dalam air limbah. Pengolahan limbah cair secara fisika pada industri batik misalnya penyaringan dan 
pengendapan. Proses penyaringan dimaksudkan untuk memisahkan padatan tersuspensi atau padatan terapung yang relatif besar seperti lilin batik, zat-zat warna, zat-zat kimia yang tidak larut, dan kotoran-kotoran pada limbah cair. Proses penyaringan ini dilakukan sebelum limbah tersebut mendapatkan pengolahan lebih lanjut. Proses pengendapan ditujukan untuk memisahkan padatan yang dapat mengendap dengan gaya gravitasi.

2. Pengolahan air limbah secara kimia bertujuan menghilangkan partikel yang tidak mudah mengendap (koloid), menetralkan limbah cair dengan cara menambahkan bahan kimia tertentu agar terjadi reaksi kimia untuk menyisihkan bahan polutan. Penambahan zat pengendap disertai dengan pengadukan cepat yang menyebabkan terjadinya penggumpalan. Hasil akhir proses pengolahan biasanya merupakan endapan yang kemudian dipisahkan secara fisika. Zat-zat pengendap yang ditambahkan biasanya adalah kapur, fero sulfat, feri sulfat, aluminium sulfat, feri klorida, dan sebagainya.

3. Pengolahan air limbah secara biologi. Pengolahan ini memanfaatkan mikroorganisme yang berada di dalam air untuk menguraikan bahan-bahan polutan. Pengolahan limbah cair secara biologi ini dipandang sebagai pengolahan yang paling murah dan efisien. Pengolahan ini digunakan untuk mengolah air limbah yang biodegradable.
Pada suatu IPAL, biasanya digunakan kombinasi dari ketiga jenis pengolahan tersebut. Pengolahan air limbah dapat dibagi atas lima tahap pengolahan, yaitu: pengolahan awal (pretreatment), pengolahan tahap pertama (primary treatment), pengolahan tahap kedua (secondary treatment), pengolahan tahap ketiga (tertiary treatment), dan pengolahan lumpur (sludge treatment). Pengolahan awal dan tahap pertama melibatkan proses fisika yang bertujuan menghilangkan padatan tersuspensi dan minyak dari aliran air limbah. Pengolahan tahap kedua dirancang untuk menghilangkan zat-zat terlarut dari air limbah yang tidak dapat dihilangkan dengan proses fisika biasa. Tahap ketiga merupakan pengolahan yang dilakukan untuk menghilangkan kontaminan tertentu yang tidak dapat dihilangkan pada pengolahan tahap pertama dan kedua (Tjokrokusumo, 1998).

\subsection{Hasil Pengujian Limbah Cair IPAL BBKB} Pengujian dilakukan di laboratorium lingkungan terakreditasi, yaitu Balai Teknik Kesehatan Lingkungan (BTKL), Kementerian Kesehatan, Provinsi DIY dengan standar peraturan daerah DIY Nomor 7 Tahun 2016 tentang baku mutu air limbah bagi industri batik. Tabel 2 menunjukkan hasil pengujian dari Laboratorium Lingkungan terhadap limbah batik pada setiap tahap pengolahan IPAL BBKB.

Tabel 2. Hasil pengujian parameter kadar pencemar

\begin{tabular}{|c|c|c|c|c|c|c|}
\hline \multirow{2}{*}{ Parameter } & \multirow{2}{*}{ Satuan } & \multicolumn{4}{|c|}{ Hasil Pengujian } & \multirow{2}{*}{ Kadar Maksimum**) } \\
\hline & & L1 & $\mathrm{L} 2$ & L3 & $\mathrm{L} 4$ & \\
\hline $\mathrm{pH}$ & - & 7.2 & 7.5 & 6.9 & 7.2 & $6.0-9.0$ \\
\hline Suhu & ${ }^{\circ} \mathrm{C}$ & 29.1 & 29.1 & 29.1 & 29.1 & $\pm 3^{\circ}$ dari suhu udara \\
\hline $\mathrm{BOD}_{5}$ & $\mathrm{mg} / \mathrm{L}$ & 2050 & 180 & 110 & 26 & 85 \\
\hline COD & $\mathrm{mg} / \mathrm{L}$ & 7817.5 & 404.4 & 264.3 & 66.2 & 250 \\
\hline TSS & $\mathrm{mg} / \mathrm{L}$ & 1315 & 530 & 86 & 12 & 60 \\
\hline
\end{tabular}

** Peraturan daerah DIY Nomor 7 Tahun 2016 tentang baku mutu air limbah bagi industri batik untuk proses basah.

Keterangan:

$\mathrm{L} 1=$ contoh uji limbah cair inlet

L2 $=$ contoh uji limbah cair pra koagulasi

L3 = contoh uji limbah cair post koagulasi

L4 = contoh uji limbah cair outlet 
Tabel 3. Efektivitas tiap tahapan pengolahan limbah terhadap penurunan atau peningkatan parameter pencemar

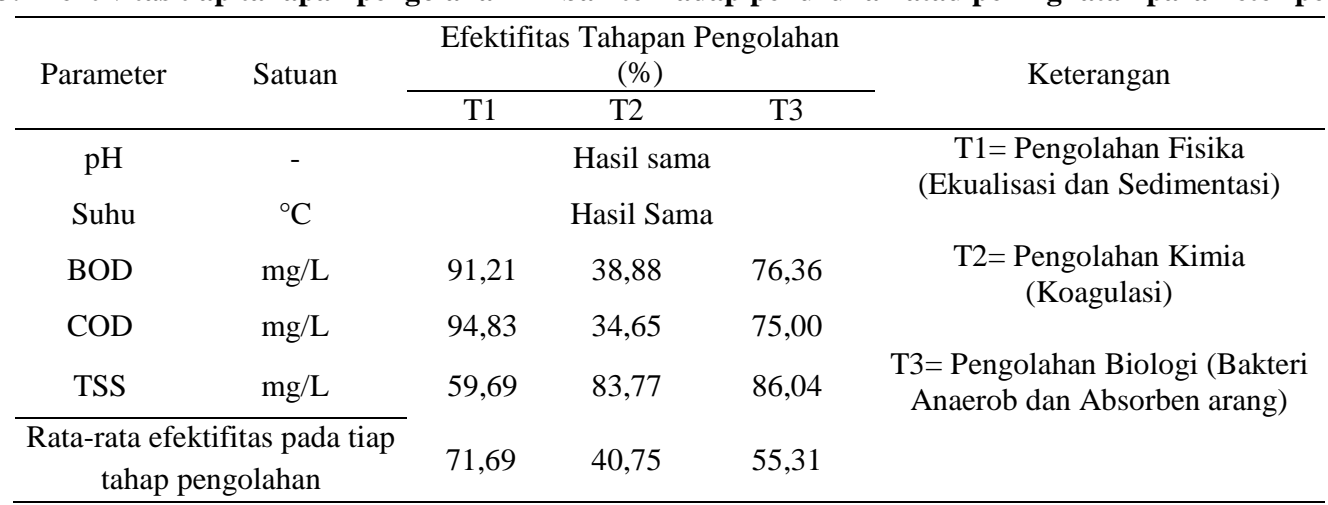

Dari keseluruhan hasil perhitungan tingkat efektivitas secara rata-rata tahapan pengolahan limbah terhadap penurunan atau peningkatan parameter pencemar yang disajikan pada Tabel 3 di atas, terlihat bahwa tahapan pengolahan limbah yang paling efektif berturut-turut proses sedimentasi; proses pengolahan kimia; pengolahan secara biologi; dengan nilai 71,69 ; 55,$31 ; 40,75 \%$.

\subsection{Parameter pH dan Suhu}

Nilai $\mathrm{pH}$ dan suhu merupakan parameter pendukung yang penting untuk dianalisis karena merupakan indikator bagi keberlangsungan proses penguraian oleh mikroorganisme di dalam suatu sistem pengolahan limbah. Pada Tabel 3 memperlihatkan bahwa pada semua tahap pengolahan, $\mathrm{pH}$ telah memenuhi baku mutu yang ditetapkan, yaitu 6-9. Tiap tahap pengolahan tidak terdapat proses yang mengakibatkan reaksireaksi yang dapat menurunkan maupun menaikkan nilai $\mathrm{pH}$, sehingga nilai $\mathrm{pH}$ tidak mengalami perubahan signifikan. Pada L3, yaitu limbah setelah proses koagulasi, $\mathrm{pH}$ lebih rendah daripada di tahap lain karena terjadi penambahan tawas yang bersifat asam. Meski demikian, nilai $\mathrm{pH}$ masih di sekitar nilai $\mathrm{pH}$ netral.

Demikian juga dengan parameter suhu, pada Tabel 3 juga menunjukkan bahwa nilai suhu ratarata yang yang tidak berpengaruh pada tahapan pengolahan sehingga nilainya selalu sama yaitu $29,1^{\circ} \mathrm{C}$. Nilai suhu tersebut masih dalam rentang suhu optimum bagi pertumbuhan bakteri, yaitu pada suhu $24-35{ }^{\circ} \mathrm{C}$. Suhu dalam limbah sangat diperlukan dalam proses pengolahan limbah.
Pada umumnya proses anaerob umumnya lebih sensitif pada suhu $25-35^{\circ} \mathrm{C}$.

\subsection{Biological Oxygen Demand (BOD) \\ Biochemical oxygen demand (BOD) atau} Kebutuhan Oksigen Biologi adalah suatu karakteristik yang menunjukkan jumlah oksigen terlarut yang diperlukan oleh mikroorganisme (biasanya bakteri) untuk mengurai atau mendekomposisi bahan organik dalam kondisi aerobik (Umaly dan Cuvin, 1988). Ditegaskan lagi oleh Boyd (1990), bahwa bahan organik yang terdekomposisi dalam $\mathrm{BOD}_{5}$ adalah bahan organik yang siap terdekomposisi (readily decomposable organic matter). Prinsip pengukuran $\mathrm{BOD}_{5}$ pada dasarnya cukup sederhana, yaitu mengukur kandungan oksigen terlarut awal $\left(\mathrm{DO}_{\mathrm{i}}\right)$ dari sampel segera setelah pengambilan contoh, kemudian mengukur kandungan oksigen terlarut pada sampel yang telah diinkubasi selama 5 hari pada kondisi gelap dan suhu tetap $\left(20{ }^{\circ} \mathrm{C}\right)$ yang sering disebut dengan $\mathrm{DO}_{5}$. Selisih $\mathrm{DO}_{\mathrm{i}}$ dan $\mathrm{DO}_{5}\left(\mathrm{DO}_{\mathrm{i}}-\mathrm{DO}_{5}\right)$ merupakan nilai BOD yang dinyatakan dalam miligram oksigen per liter $(\mathrm{mg} / \mathrm{L})$ (Haryadi 2004).

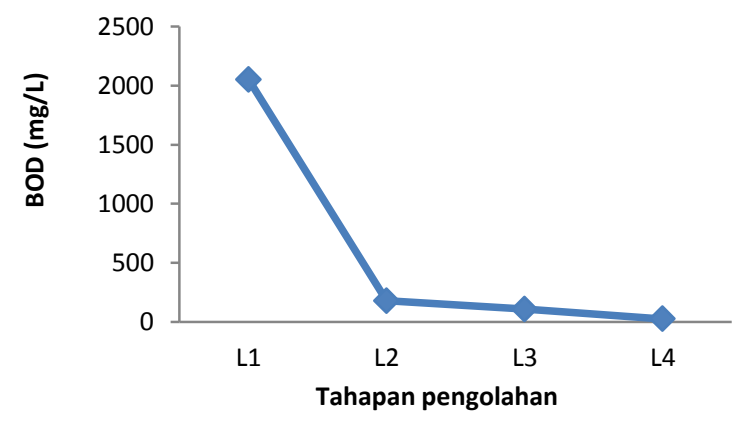

Gambar 3. Grafik penurunan nilai BOD 
Gambar 3 (grafik nilai BOD) menunjukkan bahwa nilai BOD cenderung menurun pada tiap tahapan pengolahan. Efektivitas pengolahan limbah terhadap penurunan BOD pada proses sedimentasi, penambahan bahan kimia berupa koagulan, serta proses biologi berturut-turut sebesar $91,21 \%$; 38,88\%; dan 76,36\%. Hal ini menunjukkan bahwa pengolahan limbah dengan proses sedimentasi dan proses biologi secara anaerob lebih efektif untuk menurunkan kadar BOD dalam limbah batik dibandingkan proses kimia yaitu penambahan bahan koagulan. Tingkat efektivitas paling tinggi dalam menurunkan nilai BOD terjadi pada tahapan T1 yaitu proses sedimentasi. Pada proses sedimentasi, kuantitas senyawa yang mengendap sudah tinggi. Sementara itu pengambilan sampel untuk mewakili proses sedimentasi diambil pada bak tandon. Limbah dialirkan dari bak sedimentasi ke bak tandon dengan menggunakan pompa sehingga memungkinkan masuknya oksigen pada proses ini. Hal inilah yang menyebabkan penurunan nilai BOD signifikan pada proses sedimentasi. Secara biologis di dalam filter anaerob, limbah dikontakkan dengan bakteri yang bekerja untuk menguraikan senyawa-senyawa organik menjadi senyawa yang lebih sederhana. Hal ini menyebabkan kebutuhan oksigen untuk proses penguraian senyawa juga akan berkurang

\subsection{Chemical Oxsigen Demand (COD)}

Chemical oxygen demand (COD) atau Kebutuhan Oksigen Kimia adalah jumlah oksigen yang diperlukan untuk mengurai seluruh bahan organik yang terkandung dalam air (Boyd, 1990). Pada prinsipnya pengukuran COD adalah penambahan sejumlah tertentu kalium dikromat $\left(\mathrm{K}_{2} \mathrm{Cr}_{2} \mathrm{O}_{7}\right)$ sebagai oksidator pada sampel (dengan volume diketahui) yang telah ditambahkan asam pekat dan katalis perak sulfat, kemudian dipanaskan selama beberapa waktu. Selanjutnya, kelebihan kalium bikromat ditera dengan cara titrasi. Dengan demikian kalium dikromat yang terpakai untuk oksidasi bahan organik dalam sampel dapat dihitung dan nilai COD dapat ditentukan. Kelemahannya, senyawa kompleks anorganik yang ada di perairan yang dapat teroksidasi juga ikut dalam reaksi (De Santo 1978), sehingga dalam kasus-kasus tertentu nilai COD mungkin sedikit 'over estimate' untuk gambaran kandungan bahan organik (Haryadi 2004).

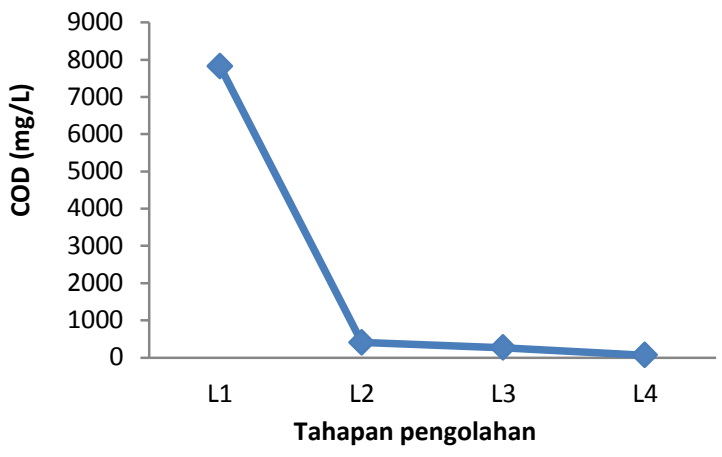

Gambar 4. Grafik penurunan nilai COD

Pada Gambar 4 memperlihatkan grafik nilai parameter COD yang cenderung menurun pada tahap pengolahan limbah. Sama seperti penurunan nilai $\mathrm{BOD}$, nilai COD paling efektif pada proses sedimentasi dengan efektivitas 94,83\%. Pada proses biologi yaitu pemanfaatan bakteri anaerob efektivitas COD juga cukup tinggi. Hal ini disebabkan oleh kemampuan bakteri dalam menguraikan zat pencemar dalam limbah. Berdasarkan hasil pengujian pada tahap akhir menunjukkan bahwa nilai COD sebesar 66 mg/L. Nilai tersebut di bawah kadar maksimum yang dibolehkan untuk limbah batik yaitu 100 $\mathrm{mg} / \mathrm{L}$. Artinya untuk parameter COD pada limbah batik BBKB yang telah diolah aman untuk dibuang ke badan air.

\subsection{Total Suspended Solid (TSS)}

Total Suspended Solid (TSS) atau total padatan tersuspensi adalah padatan yang tersuspensi di dalam air berupa bahan-bahan organik dan anorganik yang dapat disaring dengan kertas millipore berpori $0,45 \mu \mathrm{m}$. Materi yang tersuspensi mempunyai dampak buruk terhadap kualitas air karena mengurangi penetrasi matahari ke dalam badan air, sehingga kekeruhan air meningkat dan menyebabkan gangguan pertumbuhan bagi organisme produser (Sastrawijaya, 2009). Dengan kata lain, TSS menyatakan konsentrasi padatan yang tersuspensi dalam limbah cair. Proses untuk menghilangkan padatan tersuspensi dalam air limbah adalah 
proses koagulasi, sedimentasi, dan proses filtrasi atau intersepsi. Partikel yang besar dan berat mengendap pada bak sedimentasi, sedangkan yang lebih ringan ikut terbawa oleh air lalu menjadi flok dan mengendap pada bak koagulasi. Partikel yang lebih kecil lagi akan terurai pada lapisan biofilm pada anaerobic filter dan terserap oleh arang aktif.

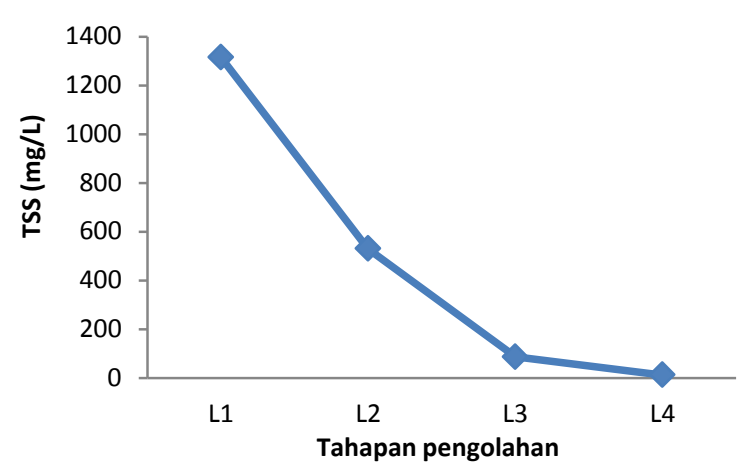

Gambar 5. Grafik penurunan nilai TSS

Pada Gambar 5 memperlihatkan pada tiap tahapan pengolahan limbah mengalami penurunan baik pada sampel limbah L1, L2, L3 dan L4. Penurunan paling signifikan terlihat pada sampel limbah L1 yaitu sampel limbah cair yang berasal dari proses pengolahan limbah cair yang terjadi pada bak penangkap lilin adalah proses pengendapan (sedimentasi). Pada saat limbah yang bersuhu tinggi didinginkan dalam bak penangkap lilin secara bersamaan terjadi pengendapan. Benda-benda padat yang mempunyai bobot jenis yang lebih besar dari nilai bobot jenis air akan mengendap dengan sendirinya. Zat yang mengandung minyak dan lemak akan mengapung. Hasil akhir proses sedimentasi limbah batik pada bak penangkap lilin, beberapa benda padat akan mengendap sedangkan malam (lilin) batik akan mengapung. Limbah cair pada bagian tengah pada bak penangkap lilin yang berwarna lebih jernih akan mengalir ke bak sedimentasi dan proses pengendapan yang sama akan berlangsung pada bak tersebut.

\section{Kesimpulan}

Pengolahan limbah IPAL BBKB merupakan sistem pengolahan limbah yang meliputi proses fisika, kimia, dan biologi. Dan tahapan pengolahan limbah yang meliputi beberapa tahapan, yaitu bak penangkap lilin (wax trap), sedimentasi, koagulasi, bak anaerob dan absorben arang, serta bak kontrol dan sumur resapan.

Dari hasil pengujian terhadap sampel limbah pada beberapa tahapan pengolahan IPAL BBKB hampir semua mengalami penurunan kadar pencemar. Berdasarkan perhitungan nilai efektivitas pengolahan IPAL BBKB paling tinggi berturut-turut pada proses pengolahan fisika dengan cara sedimentasi (71,69\%); pengolahan biologis dengan pemanfaatan bakteri anaerob $(55,31 \%)$; dan pengolahan kimia dengan penambahan koagulasi (40,75\%).

Pada sampel akhir limbah sebelum dibuang ke lingkungan, nilai kadar pencemar di bawah nilai baku mutu limbah cair bagi industri batik yang ditetapkan oleh pemerintah sehingga dikatakan limbah hasil pengolahan IPAL BBKB aman terhadap lingkungan. Hal tersebut menunjukkan bahwa pengolahan limbah IPAL BBKB sudah efektif.

\section{Saran}

Perlu ada penelitian lebih lanjut untuk mengidentifikasi limbah cair di IKM batik agar mengoptimalkan proses pengolahan limbah pada IKM batik.

\section{Daftar Pustaka}

Boyd CE, 1990, Water quality in ponds for aquaculture, Auburn (AL): Alabama Agricultural Experiment Station, Auburn University.

De Santo R.S., 1978, Concepts of applied ecology, Springer-Verlag, Heidelberg Science Library.

Eskani I.N., Ivone De Carlo, Suleman, 2005, Efektifitas pengolahan air limbah dengan cara kimia dan biologi, Jurnal Dinamika Kerajinan dan Batik, 22, 16-27

Haryadi S., 2004, BOD dan COD sebagai Parameter Pencemaran Air Dan Baku Mutu Air Limbah, Institut Pertanian Bogor (IPB), Bogor.

Kurniawan M.W., Purwanto P., Sudarso S., 2013, Stratergi pengelolaan air limbah sentra 
UMKM batik yang berkelanjutan di kabupaten Sukoharjo, Jurnal Ilmu Lingkungan, 11(2),62-72.

Manurung R., Hasibuan R., Irvan, 2004, Perombakan Zat Warna Azo secara Anaerob-aerob. Universitas Sumatera Utara, Medan.

Muljadi, Muniarti T., 2013, Pengolahan limbah batik cetak dengan menggunakan metode filtrasi-elektrolisis untuk menentukan efisiensi penurunan parameter COD, BOD, dan logam berat $(\mathrm{Cr})$ setelah perlakuan fisika-kimia, Ekuilibrium, 12 (1),27-36.

Purwaningsih I., 2008, Pengolahan limbah cair industri batik CV. Batik Indah Raradjonggrang Yogyakarta dengan metode elektrokoagulasi ditinjau dari parameter Chemical Oxygen Demand (COD) dan Warna. Skripsi, Universitas Islam Indonesia, Yogyakarta.
Rohasliney H., Subki N.S., 2011, A Preliminary Study on Batik Effluent in Kelantan State: A Water Quality Perspectiv. International Conference on Chemical, Biological, and Environment Science 2011, Bangkok, Thailand.

Satrawijaya A. T., 2009, Pencemaran Lingkungan. Rineka Cipta, Jakarta

Tjokrokusumo, 1998, Pengantar Teknik Lingkungan, Sekolah Tinggi Teknik Lingkungan, Yogyakarta.

Umaly R.C., Cuvin M.L.A. 1988, Limnology: Laboratory and Field Guide, Physicochemical Factors, Biological Factors, Metro Manila, Manila.

Wardhana W.A., 2004, Dampak Pencemaran Lingkungan, Andi Yogyakarta, Yogyakarta 